Original Article

\title{
IN VITRO ANTIOXIDANT AND IN VIVO ANTI-INFLAMMATORY ACTIVITY OF THE AERIAL PART OF BLUMEA ERIANTHA DC
}

\author{
URMILA U. TAMBEWAGH, SUPADA RAMBHAU ROJATKAR*
}

R\&D Center in Pharmaceutical Sciences and Applied Chemistry, Bharati Vidyapeeth Deemed University, Poona College Pharmacy campus, Erandwane, Pune-411038, India.

Email: srojatkar@yahoo.com

Received: 01 Mar 2018 Revised and Accepted: 05 Jun 2018

\section{ABSTRACT}

Objective: Objective of the present study was to carry out in vivo anti-inflammatory and in vitro antioxidant activity of methanol extract of aerial part of the Blumea eriantha DC belonging to family Asteraceae.

Methods: The shade dried aerial part of B. eriantha $(0.5 \mathrm{~kg})$ was powdered and extracted with methanol $(1.5 \times 3 \mathrm{~L})$ at room temperature $(24 \mathrm{~h} \times 3)$. After filtration combined all the three extracts and were concentrated on rotary evaporator under reduced pressure at $40{ }^{\circ} \mathrm{C}$, thereby providing crude methanol extract which was subsequently employed for further studies. Anti-inflammatory effect was studied by carrageenan-induced paw edema model in rats at dose level 100,200 , and $400 \mathrm{mg} / \mathrm{kg}$. Acute oral toxicity study and in vitro antioxidant potential of the extract was also studied. The in vitro antioxidant activity of methanol extract of aerial part of Blumea eriantha DC was evaluated against 1,1-diphenyl-2-picryl hydrazyl (DPPH), hydrogen peroxide $\left(\mathrm{H}_{2} \mathrm{O}_{2}\right)$ and hydroxyl $(\mathrm{OH})$ radical scavenging and reducing power assays.

Results: The results indicate that methanol extract of Blumea eriantha (BEME, $400 \mathrm{mg} / \mathrm{kg}$ ) exhibited significant inhibition $(p<0.001)$ of increase in paw edema at $5^{\text {th }} \mathrm{h}$. IC $\mathrm{C}_{50}$ value of BEME showed significant antioxidant activity. The extract exhibits promising free radical scavenging effect of DPPH, $\mathrm{H}_{2} \mathrm{O}_{2}$, OH and reducing power in a dose-dependent manner up to $100 \mu \mathrm{g} / \mathrm{ml}$ concentration while the reference standard Ascorbic acid demonstrated more scavenging potential than the methanol extract of Blumea eriantha The methanol extract was found to be safe at the dose of $2000 \mathrm{mg} / \mathrm{kg}$.

Conclusion: The results of the experimental study confirmed that methanol extract of Blumea eriantha DC possesses significant anti-inflammatory and antioxidant activity.

Keywords: Blumea eriantha DC, Anti-inflammatory, Antioxidant

(c) 2018 The Authors. Published by Innovare Academic Sciences Pvt Ltd. This is an open access article under the CC BY license (http://creativecommons.org/licenses/by/4.0/) DOI: http://dx.doi.org/10.22159/ijpps.2018v10i7.25588

\section{INTRODUCTION}

The assault of contagious microorganisms such as bacteria, viruses or fungi on host usually leads to Inflammation reside in particular tissues. Inflammation plays an important role not only intissue injury, cell death, cancer, ischemia but also in degeneration and tissue enhancing treatment. Inflammation and pain allied with each other. Reactive oxygen species (ROS) play a crucial role in the instigation of free-radical reaction [1]. Antioxidants are compounds that can prevent or inhibit oxidation chain reaction process in living cells. The free radicals involved in the oxidative damage of DNA, proteins, lipids, and lipoproteins. Inflammation coupled with oxidative stress can influence much neurogenerative disorder like arthritis, cancer of lungs, cervix, hepatotoxicity, neurotoxicity, nephrotoxicity, Alzheimer's, etc. Application of traditional medicinal plants with analgesic, anti-inflammatory effects has recently gained popularity world wide over non-steroidal anti-inflammatory drug available in the market because of their natural origin and fewer side effects [2]. Therefore plants have served as a source of natural and safer new drugs for the treatment of inflammation and pain [3].

The genus Blumea includes 25-30 species. The other species of Blumea like Blumea lacera shows anthelmintic, antidiarrhoeal, antidiabetic activity [4] analgesic, hypothermic, and tranquilizing activities have been reported from the essential oil of Blumea $[5,6]$ Blumea balsamifera biologically studied for their cytotoxicity against cancer cells. Blumea eriantha DC is commonly known as' Nimurdi'(Marathi) and Kukronda in Hindi, a small perennial herb, up to $1 \mathrm{~m}$ in height covered with white and silky hair, dichotomously branched, dispersed in Karnataka, Maharashtra, Uttar Pradesh, Madhya Pradesh, Bihar, and Orissa. Juice of the herb used as 'carminative.' The essential oil extracted from leaves and stem showing potent antibacterial, antifungal and insecticidal activity. The plant has been applied to treat cholera and diarrhea traditionally and also used as a diuretic. It also used in Rheumatic pain, cough and the common cold. Antioxidant potential and cytotoxicity of leaf extract were reported [7]. The plant also exhibits significant cholesterol-lowering effect [5, 7].

However, there have been no studies on its in vivo anti-inflammatory and in vitro antioxidant activity of methanol extract of (aerial part) of Blumea eriantha $D C$. Hence the objective of the study was to investigate the anti-inflammatory activity of the extract of Blumea eriantha in animal model, and in vitro evaluation of antioxidant activity of the extract.

\section{MATERIALS AND METHODS}

\section{Procurement and authentication of plant}

Blumea eriantha Dc was identified and authenticated by A. Benniamin, Scientist D, Botanical Survey of India, Pune and voucher specimen (No. BSI/WRC/cert/2015/43) was deposited at that institute.

\section{Drugs and chemicals}

Carrageenan, DPPH (1, 1-diphenyl-2-picrylhydrazyl), Methanol (Molychem, India), Diclofenac (gift sample from Emcure Pharmaceuticals Ltd., Pune) and all other chemicals and solvents used were of analytical grade.

\section{Preparation of extract}

The aerial part of B. eriantha was shade dried and powdered. The total $0.5 \mathrm{~kg}$ powder was extracted by maceration with using 
methanol (1.5 lit x3) solvent at room temperature (24hx3). Then combined all the three collected extracts after filtration and concentrated on a rotary evaporator under reduced pressure at $40{ }^{\circ} \mathrm{C}$ to obtain $35.0 \mathrm{gm}, 7.0 \%$ (BEME) greenish viscous methanol extract.

\section{Experimental animals and approval}

Female Wistar rats (10-12 w of age, 150-200 g) and Swiss albino mice (male and female, $4 \mathrm{w}$ of age, 20-25 g) were acquiredfrom National Institute of Biosciences, Pune. Animals were housed at $24 \pm 1{ }^{\circ} \mathrm{C}$ and relative humidity of $65 \pm 10 \%$ and standard environmental conditions (12 h light and $12 \mathrm{~h}$ dark cycle) in the animal house. The animals were fed with standard pellet rodent diet and water was provided ad libitum. All the experimental protocols used in this study were approved by Institutional Animal Ethical Committee (CPCSEA/PCH/02/2014-15).

\section{Acute oral toxicity study}

Healthy male and female Swiss albino mice were subjected to acute oral toxicity studies as per OECD guidelines-425 [8-10]. The animals were fasted overnight and divided into a group of 5 animals. Methanol extract of Blumea eriantha DC was administered orally at one dose level of, $175 \mathrm{mg} / \mathrm{kg}, 550 \mathrm{mg} / \mathrm{kg}, 1750 \mathrm{mg} / \mathrm{kg}$, and 2000 $\mathrm{mg} / \mathrm{kg}$ body weight. The mice were observed continuously for behavioral, respiratory or autonomic responses, restlessness, convulsions, tremors, salivation, diarrhea, and mortality for $2 \mathrm{~h}$ and any sign of toxicity or mortality up to $48 \mathrm{~h}$.

\section{Anti-inflammatory activity}

\section{Carrageenan induced rat paw edema}

Wistar rats of either sex weighing 170-200 g were divided in following groups $(\mathrm{n}=6) \mathrm{viz}$;

Group I-Vehicle (2\% Tween 80),

Group II-Standard (Diclofenac $10 \mathrm{mg} / \mathrm{kg}$, p. o.),

Group III-BEME (100 mg/kg, p. o.).

Group IV-BEME (200 mg/kg, p. o.).

Group V-BEME (400 mg/kg, p. o.).

Inflammation was produced by injecting $0.1 \mathrm{ml}$ of $1.0 \%$ lambada carrageenan (Sigma Co; USA) in sterile normal saline in to the sub plantar region of the right hind paw of the rat. Rats were presented orally with BEME, and Diclofenac $1 \mathrm{~h}$ before the carrageenan injection. The paw volume of the rat was measured from $0-6 \mathrm{~h}$, at an hourly interval using plethsmometer (Model: 2888, Almemo, Germany). The mean changes in injected paw volume with respect to initial paw volume were calculated. Percentage inhibition of paw volume between treated and control group was calculated by the following formula.

$\%$ Inhibition $=\left(1-\mathrm{VT} / \mathrm{VC}^{*} 100\right)$

Where, VT and VC are the mean increase in paw volume in treated and control groups, respectively.

\section{In vitro antioxidant activity of Blumea eriantha}

The ability of the methanol extract (BEME) of the aerial part of the plant and ascorbic acid to scavenge 1,1-diphenyl-2-picrylhydrazyl (DPPH), hydrogen peroxide $\left(\mathrm{H}_{2} \mathrm{O}_{2}\right)$, hydroxyl $(\mathrm{OH})$ radical and reducing power was determined according to the methods described $[1,11,12$,$] .$

\section{DPPH free radical scavenging assay}

The antioxidant activity of the methanol extract (BEME) and ascorbic acid were assessed on the basis of the radical scavenging effect of the stable DPPH free radical. The $(10-100 \mu \mathrm{g} / \mathrm{ml}$ of each extract or standard was added to $2 \mathrm{ml}$ of DPPH in methanol $(0.33 \%)$ in a test tube. After incubation at $37^{\circ} \mathrm{C}$ for $30 \mathrm{~min}$, the absorbance of each solution was determined at $517 \mathrm{~nm}$ using a spectrophotometer. The corresponding blank reading was also taken and the remaining DPPH was calculated by using the following formula,
DPPH radical scavenging activity $(\%)=[$ Abs (control) - Abs (standard) $/$ Abs (control)] x100.

Where, Abs (control): Absorbance of DPPH radical+methanol

Abs (standard): Absorbance of DPPH radical+extract/standard.

The $\mathrm{IC}_{50}$ value calculated denotes the concentration of the sample required to scavenge $50 \%$ of DPPH radical.

\section{Hydrogen peroxide radical scavenging assay}

A solution of hydrogen peroxide $(2 \mathrm{~m} \mathrm{~mol} / \mathrm{l})$ was prepared in phosphate buffer (pH 7.4). Extracts $(10-100 \mu \mathrm{g} / \mathrm{ml})$ were added to hydrogen peroxide solution $(0.6 \mathrm{ml})$. The absorbance of hydrogen peroxide at $230 \mathrm{~nm}$ was determined after 10 min against a blank solution containing phosphate buffer without hydrogen peroxide. For each concentration, a separate blank sample was used for background subtraction. The percentage scavenging activity of hydrogen peroxide by compound 1 and ascorbic acid was calculated using the following formula,

$\%$ scavenging activity $\left[\mathrm{H}_{2} \mathrm{O}_{2}\right]=[\mathrm{Abs}$ (control) $-\mathrm{Abs}$ (standard) $/ \mathrm{Abs}$ (control) $]$ $\mathrm{x} 100$

Where, Abs (control): Absorbance of the control and

Abs (standard): Absorbance of the extract/standard.

The $\mathrm{IC}_{50}$ value calculated denotes the concentration of the sample required to scavenge $50 \%$ of hydrogen peroxide radical.

\section{Hydroxyl radical scavenging assay}

The assay was performed by adding $0.1 \mathrm{ml}$ of $1 \mathrm{mmol}$ EDTA, $0.01 \mathrm{ml}$ of $10 \mathrm{mmol} \mathrm{FeCl} 3,0.1 \mathrm{ml}$ of $10 \mathrm{mmol} \mathrm{H}_{2} \mathrm{O}_{2}, 0.36 \mathrm{ml}$ of $10 \mathrm{mmol}$ deoxyribose, $1.0 \mathrm{ml}$ of different dilutions of the extract and ascorbic acid $(10-100 \mu \mathrm{g} / \mathrm{ml})$ dissolved in distilled water, $0.33 \mathrm{ml}$ of phosphate buffer ( $50 \mathrm{mmol}, \mathrm{pH} 7.4$ ) and $0.1 \mathrm{ml}$ of ascorbic acid in sequence. The mixture was then incubated at $37^{\circ} \mathrm{C}$ for $1 \mathrm{~h}$. A $1.0 \mathrm{ml}$ portion of the incubated mixture was mixed with $1.0 \mathrm{ml}$ of $10 \%$ TCA and $1.0 \mathrm{ml}$ of $0.5 \%$ TBA (in $0.025 \mathrm{M} \mathrm{NaOH}$ containing $0.025 \%$ butylatedhydroxyanisole to develop the pink chromogen measured at $532 \mathrm{~nm}$. The hydroxyl radical scavenging activity of the extract is reported as \% inhibition of deoxyribose degradation and is calculated as,

$\mathrm{OH}$-scavenged (\%) $=\left[\mathrm{Abs}\right.$ (control) $-\mathrm{Abs}$ (standard) $_{\text {(Abs }} /$ (control) $] \times 100$.

Where, Abs (control): Absorbance of the control reaction and

Abs (standard): Absorbance of the extract/standard.

The $\mathrm{IC}_{50}$ value calculated denotes the concentration of the sample required to scavenge $50 \%$ of hydroxyl radical.

\section{Statistical analysis}

Data are expressed as mean \pm SEM, and statistical analysis was carried out by two-way ANOVA followed by Bonferroni's post hoc test. All statistical analyses were performed using Graph Pad Prism software (Graph Pad Software, San Diego, California, USA). Differences with a value of $p<0.05$ were considered statistically significant.

\section{RESULTS AND DISCUSSION}

\section{RESULTS}

\section{Acute oral toxicity study}

Administration methanol extract (BEME, $2000 \mathrm{mg} / \mathrm{kg}$, p. o.) did not produce any behavioral abnormalities and mortality. Hence, the extract was found to be safe at the dose of $2000 \mathrm{mg} / \mathrm{kg}$. Therefore, three doses of BEME $(100,200$ and $400 \mathrm{mg} / \mathrm{kg} \mathrm{b}$. w) were selected for the anti-inflammatory study.

\section{Anti-inflammatory activity of BEME extract in carageenan- induced paw edema}

Effect of BEME on inhibition of right hind paws edema on carrageenan-induced inflammation in rats

The rats were pretreated with all the doses of extract and diclofenac for $1 \mathrm{~h}$ before the injection of carrageenan caused inhibition of the 
increase in paw edema from $1 \mathrm{~h}$ to $5 \mathrm{~h}$. Diclofenac $(10 \mathrm{mg} / \mathrm{kg})$ caused significant $(p<0.01$ and $p<0.001)$ inhibition of the increase in paw edema at $3^{\text {rd }}$ and $5^{\text {th }} \mathrm{h}$ respectively. The inhibitory effect of the diclofenac $(10 \mathrm{mg} / \mathrm{kg})$ was recorded $(10.38 \%)$ at $3^{\text {rd }} \mathrm{h}$ and $(30.94 \%)$ at $5^{\text {th }} \mathrm{h} .400 \mathrm{mg} / \mathrm{kg}$ caused significant $(p<0.001)$ inhibition of the increase in paw edema at $5^{\text {th }} \mathrm{h}$. The inhibitory effect of BEME $(400 \mathrm{mg} / \mathrm{kg})$ was recorded at $3^{\text {rd }} \mathrm{h}(8.21 \%)$ and $5^{\text {th }} \mathrm{h}(21.69 \%)$ respectively. The inhibitory effect of BEME (100 and $200 \mathrm{mg} / \mathrm{kg}$ ) were recorded at $3^{\text {rd }} \mathrm{h}$ $(2.95$ and $5.77 \%)$ and $5^{\text {th }} \mathrm{h}(10.16$ and $14.16 \%)$ respectively. The inhibition elicited by the $400 \mathrm{mg} / \mathrm{kg}$ was comparable to that of diclofenac (Table 1).

Table 1: Effect of BEME on inhibition of right hind paws edema on carrageenan-induced inflammation in rats

\begin{tabular}{|c|c|c|c|c|c|c|}
\hline \multirow[t]{2}{*}{ Treatment Groups } & \multicolumn{3}{|c|}{ Change in paw edema volume (ml) } & \multicolumn{3}{|c|}{ \% Inhibition at } \\
\hline & $1 \mathrm{~h}$ & $3 \mathbf{h ~}$ & $5 \mathrm{~h}$ & $1 \mathrm{~h}$ & $3 \mathbf{h}$ & $5 \mathrm{~h}$ \\
\hline Carrageenan control & $0.79 \pm 0.010$ & $1.30 \pm 0.029$ & $1.46 \pm 0.028$ & - & - & - \\
\hline Diclofenac10 mg/kg & $0.78 \pm 0.015$ & $1.17 \pm 0.024^{* *}$ & $1.01 \pm 0.034^{* * *}$ & 0.84 & 10.38 & 30.94 \\
\hline BEME(100 mg/kg) & $0.79 \pm 0.015$ & $1.26 \pm 0.015^{\mathrm{ns}}$ & $1.31 \pm 0.017^{* * *}$ & 0.00 & 2.95 & 10.16 \\
\hline BEME (200 mg/kg) & $0.79 \pm 0.012$ & $1.23 \pm 0.015^{\mathrm{ns}}$ & $1.25 \pm 0.015^{* * *}$ & 0.21 & 5.77 & 14.16 \\
\hline BEME (400 mg/kg) & $0.79 \pm 0.024$ & $1.19 \pm 0.031^{\mathrm{ns}}$ & $1.14 \pm 0.035^{* * *}$ & 0.63 & 8.21 & 21.69 \\
\hline
\end{tabular}

Data are expressed as mean \pm SEM; $n=6$ rats per group. Two way ANOVA followed by Bonferroni's post hoc test when compared with carrageenan control ${ }^{*} p<0.05,{ }^{* *} p<0.01,{ }^{* * *} p<0.001$.

\section{In vitro anti-oxidant activity of extract (BEME)}

Effect of extract and ascorbic acid on DPPH free radical scavenging assay

The extract exhibits promising free radical scavenging effect of DPPH in a dose-dependent manner up to a concentration of $100 \mu \mathrm{g} / \mathrm{ml}$ in this assay. The more radical scavenging potential of ascorbic acid was also demonstrated more which used as reference standard. The $\mathrm{IC}_{50}$ values of extract and ascorbic acid were 91.5 and $56 \mu \mathrm{g} / \mathrm{m}$ respectively (Table 2)

Effect of extract and ascorbic acid on hydrogen peroxide free radical scavenging assay

In this assay, the radical scavenging of hydrogen peroxide leads to exhibit promising free radical scavenging effect of extract in a dosedependent manner up to a concentration of $100 \mu \mathrm{g} / \mathrm{ml}$. The reference standard ascorbic acid also exhibit more radical scavenging potential. The $\mathrm{IC}_{50}$ values of extract and ascorbic acid were 82 and $74 \mu \mathrm{g} / \mathrm{ml}$ respectively (Table 2 )

Effect of extract and ascorbic acid on hydroxyl free radical scavenging assay

The percentage scavenging of hydroxyl radicals by extract was increased in a dose-dependent manner. $(10-100 \mu \mathrm{g} / \mathrm{ml})$. The ascorbic acid (standard) also showed scavenging effect. The $\mathrm{IC}_{50}$ values of extract and ascorbic acid were 61 and $44 \mu \mathrm{g} / \mathrm{ml}$ respectively (Table 2).

\section{Effect of extract and ascorbic acid on reducing power assay}

The reducing power of extract as a function of time is presented in Table 2. The reducing power of extract and ascorbic acid increased with increase in concentration.

Table 2: Effect of extract (BEME) and ascorbic acid on DPPH free radical scavenging assay, $\mathrm{H}_{2} \mathrm{O}_{2}$ scavenging assay and $\mathrm{OH}$ scavenging assay and reducing power assays

\begin{tabular}{|c|c|c|c|c|c|c|c|c|}
\hline \multirow[t]{2}{*}{$\begin{array}{l}\text { Conc } \\
\mu \mathrm{g} / \mathrm{ml}\end{array}$} & \multicolumn{2}{|c|}{$\begin{array}{l}\text { DPPH free radical scavenging } \\
\text { assay. } \mathrm{IC}_{50} \mu \mathrm{g} / \mathrm{ml}\end{array}$} & \multicolumn{2}{|c|}{$\begin{array}{l}\text { Hydrogen peroxide radical } \\
\text { scavenging assay. } \mathrm{IC}_{50} \mu \mathrm{g} / \mathrm{ml}\end{array}$} & \multicolumn{2}{|c|}{$\begin{array}{l}\text { Hydroxyl radical scavenging } \\
\text { assay. } \mathrm{IC}_{50} \mu \mathrm{g} / \mathrm{ml}\end{array}$} & \multicolumn{2}{|c|}{$\begin{array}{l}\text { Reducing power assay } \\
\text { (absorbance) }\end{array}$} \\
\hline & Extract & AA & Extract & AA & Extract & AA & Extract & AA \\
\hline 10 & 19.93 & 22.39 & 5.61 & 14.76 & 27.59 & 31.35 & 3.28 & 3.233 \\
\hline 20 & 21.81 & 27.46 & 16.84 & 28.07 & 32.45 & 40.73 & 3.411 & 3.268 \\
\hline 40 & 25.95 & 45.33 & 26.4 & 39.09 & 40.62 & 47.9 & 3.516 & 3.325 \\
\hline 60 & 29.34 & 50.63 & 39.09 & 46.57 & 49.67 & 59.16 & 3.53 & 3.429 \\
\hline 80 & 42.61 & 61.97 & 48.86 & 51.35 & 59.93 & 69.32 & 3.551 & 3.441 \\
\hline 100 & 54.97 & 65.04 & 59.25 & 62.58 & 66.45 & 73.29 & 3.62 & 3.471 \\
\hline $\mathrm{IC}_{50}$ & 91.5 & 56 & 82 & 74 & 61 & 44 & - & - \\
\hline
\end{tabular}

AA: Ascorbic acid; DPPH: 2,2 Diphenyl-1-picrylhydrazyl; $\mathrm{H}_{2} \mathrm{O}_{2}$ : Hydrogen peroxide; $\mathrm{OH}$ : Hydroxyl. The reducing power of $\mathrm{BEME}$ as a function of time.

\section{DISCUSSION}

Plants are a major key source of drug or treatment approach in different traditional medicinal systems. A large number of peoples believe in herbal based medicines for basic healthcare requirements. Several natural products are applied to release symptoms of pain and inflammation in various traditional medicinal systems. Pain and inflammationare associated with physiopathology of various diseases like arthritis, cancer and vascular diseases. Blumea eriantha $D C$ is reported to antibacterial, antifungal and insecticidal, anticancer properties. This plant has been traditionally used as a diuretic and also for the treatment of cholera and diarrhea [7]. However, till now, there has been no investigation supporting the anti-inflammatory properties of this plant. Hence, in the present investigation, we have evaluated it's in vivo anti-inflammatory potential against carrageenan-induced paw edema model in rats and in vitro antioxidant activity. Acute oral toxicity study performed at the dose of $2000 \mathrm{mg} / \mathrm{kg}$ revealed the non-toxic nature of methanol extract of this plant. There were no toxic reactions or mortality found with extract. The rats were pretreated with all the doses of extract and diclofenac for $1 \mathrm{~h}$ before the injection of carrageenan caused inhibition of the increase in paw edema from $1 \mathrm{~h}$ to $5 \mathrm{~h}$. Diclofenac $(10 \mathrm{mg} / \mathrm{kg})$ caused significant $(p<0.01$ and $p<0.001)$ inhibition of the increase in paw edema at $3^{\text {rd }}$ and $5^{\text {th }} \mathrm{h}$ respectively. The inhibitory effect of the diclofenacat $10 \mathrm{mg} / \mathrm{kg}$ was recorded $(10.38 \%)$ at $3^{\text {rdhand }}(30.94 \%)$ at $5^{\text {th }} \mathrm{h} .400 \mathrm{mg} / \mathrm{kg}$ caused significant $(p<0.001)$ inhibition of the increase in paw edema at $5^{\text {th }} \mathrm{h}$. The inhibitory effect of the $400 \mathrm{mg} / \mathrm{kg}$ was recorded at $3^{\text {rd }}$ $\mathrm{h}(8.21 \%)$ and $5^{\text {th }} \mathrm{h}(21.69 \%)$ respectively.

The inhibitory effect of the 100 and $200 \mathrm{mg} / \mathrm{kg}$ were recorded at $3^{\text {rd }}$ $\mathrm{h}(2.95$ and $5.77 \%)$ and $5^{\text {th }} \mathrm{h}(10.16$ and $14.16 \%)$ respectively. The inhibition triggered by the $400 \mathrm{mg} / \mathrm{kg}$ was comparable to that of diclofenac. According to literature, plant exhibit potentialantiinflammatory activities due to the presence of phenolic compounds, flavonoids and sesquiterpene lactones [13]. 
Escalating confirmation showed that free radicals lead to oxidative stress that plays a significant role in inflammatory processes whereas free radical and antioxidants scavengers played a crucial role in the reduction of inflammation [1, 14-19]. The close involvement of reactive oxygen species (ROS) such as superoxide anion, hydrogen peroxide $\left(\mathrm{H}_{2} \mathrm{O}_{2}\right)$, and hydroxyl radical $(\mathrm{OH})$ resulted in many dreaded diseases like cancer, Alzheimer's disease, aging, inflammation, rheumatoid arthritis, and atherosclerosis [20, 21]. Now a day various studies havebeen reported on the crucial role of antioxidant and radical-scavenging mechanism in various antiinflammatory, anti-arthritic, anti-diabetic, anti-convulsant, antiulcer, cardioprotective, hepatoprotective, neuroprotective, and wound healing potential of drugs [22-24]. The 2-diphenyl-1picrylhydrazyl (DPPH), $\mathrm{H}_{2} \mathrm{O}_{2}$ and hydroxyl radical scavenging assay are few of them. Several antioxidants that quickly reacts with peroxyl radicals may be slowly reacted or even inert to DPPH [25]. The effect of antioxidants on DPPH radical scavenging is thought to be due to their hydrogen donating ability. In the present study, the methanol extract of Blumea eriantha showed scavenging activity in a concentration-dependent manner, and $\mathrm{IC}_{50}$ of methanol extract for $\mathrm{DPPH}$ is $91.5 \mu \mathrm{g} / \mathrm{ml}$, Hydrogen peroxide appears naturally in various elements including air, water, the human body, plants, microorganisms, food, and beverages. [26-27]. However, the formation of hydroxyl radicals from its rapid decomposition in to oxygen and water can cause DNA damage via lipid peroxidation [28].

In the present investigations, $\mathrm{IC}_{50}$ of methanol extract for $\mathrm{H}_{2} \mathrm{O}_{2}$ is $82.0 \mu \mathrm{g} / \mathrm{ml}$,and $\mathrm{IC}_{50}$ of methanol extract for $\mathrm{OH}$ is $61.0 \mu \mathrm{g} / \mathrm{ml}$ which suggest that Blumea eriantha has good antioxidant potential. It has been reported that the coupling of antioxidant activity and reducing power may result in significant reflection of the antioxidant activity [29-31]. The results of the present investigation are in accordance with the findings of the previous investigators. The methanol extract exhibits good reducing power abilitywhich might potentiate its antioxidant property.

\section{CONCLUSION}

The experimental study demonstrated the anti-inflammatory as well as the anti-oxidant activity of Blumea eriantha in a dose-dependent manner. Mainly BEME $400 \mathrm{mg} / \mathrm{kg}$ was found to be highly effective. The current study justified and supported the ethnopharmacological use of the plant scientifically as an anti-inflammatory agent to treat inflammation. Further attempts will be made to isolate and characterize the active component/s which are responsible for the anti-inflammatory activity of the methanol extract of Blumea eriantha DC.

\section{ACKNOWLEDGMENT}

The authors would like to acknowledge to Dr. S. S. Kadam, Former Vice-Chancellor and Dr. K. R. Mahadik, Principal, Poona College of Pharmacy, Bharati Vidyapeeth Deemed University, Pune, India, for providing necessary facilities to carry out the research work.

\section{AUTHORS CONTRIBUTIONS}

Urmila Tambewagh conducted the experiments and also prepared the manuscript. Supada Rojatkar was involved in the planning of the experimental work and in assisting the manuscript preparation. Both the authors have read and approved the content of the manuscript.

\section{ABBREVIATION}

Blumea eriantha methanol extract-BEME, MeOH-Methanol, Percentage-\%, Temperature- ${ }^{\circ} \mathrm{C}$, kg-kilogram, ml-milli litre, $\mu \mathrm{g} / \mathrm{ml}$ microgram/milli litre.

\section{CONFLICT OF INTERESTS}

The authors declare that there are no conflict of interest

\section{REFERENCES}

1. Honmore V, Kandhare A, Kadam P, Bodhankar S. Isolates of Alpinia officinarum Hance as COX-2 inhibitors: evidence from anti-inflammatory, antioxidant and molecular docking studies. Int Immunopharmacol 2016;33:8-17.
2. Bihani GV, Rojatkar SR, Bodhankar SL. Investigation of in vivo analgesic and anti-inflammatory activity in rodents and in vitro antioxident activity of extracts of whole plant of Cyathocline purpurea. Int J Pharm Pharm Sci 2014;6:492-8.

3. Bhagyasri Y, Lavakumar M, Divya Sree MS, Ashok Kumar CK. An overview on anti-inflammatory activity of Indian herbal plants. Int J Res Pharm Nano Sci 2015;4:1-9.

4. Pattewar AM, Dawalbaje AB, Gundale PB, Kavtikar PG, Yerawar $\mathrm{PP}$, et al. Phytochemistryical and anthelmintic studies on Blumea lacera burm. f. Indo Global J Pharm Sci 2012;2:390-6.

5. Singh UP, Parthasarathy R. Comparative antidiarrhoel activity of ethanolic extract of root of Blumea lacera and Blumea eriantha DC on experimental animals. J Pharm Biomed Sci 2012;17:1-4.

6. Khurshid J, Sukalyan K, Abdul B. Evaluation of antimicrobial and cytotoxic activities of the mehanolic and petroleum ether extract of Blumea lacera Burm. f in Bangladesh. J Pharmacogn Phytochem 2014;2:104-8.

7. Gore M, Desai NS. Characterization of phytochemicals and evaluation of anti-cancer potential of Blumea eriantha $D C$. Physiol Mol Biol Plants 2014;20:475-86.

8. OECD, Test No. 425: Acute Oral Toxicity: Up-and-down Procedure. OECD Guidelines for the Testing of Chemicals, Section 4: Health Effects, OECD Publishing, Paris, OECD Publishing; 2008.

9. Kandhare AD, Bodhankar SL, Mohan V, Thakurdesai PA. Acute and repeated dose ( $28 \mathrm{~d}$ ) oral toxicity study of glycosides based standardized fenugreek seed extract in laboratory mice. Regul Toxicol Pharmacol 2015;72:323-34.

10. Kandhare AD, Bodhankar SL, Mohan V, Thakurdesai PA. Acute and repeated doses(28 d) oral toxicity study of Vicenin-1, a flavonoid glycoside isolated from fenugreek seeds in laboratory mice. Regul Toxicol Pharmacol 2016;81:522-31.

11. Ruikar AD, Khatiwora E, Ghayal N, Misar A, Mujumdar A, Puranik V, et al. Studies on aerial parts of Artemisia pallens wall for phenol, flavonoid and evaluation of antioxidant activity. J Pharm Bioallied Sci 2011;3:302-5.

12. Ganapaty S, Chandrashekhar V, Chitme H, Narsu ML. Free radical scavenging activity of gossypin and nevadensin: an in vitro evaluation. Indian J Pharm 2007;39:281-3.

13. Al-Saghir J, Al-Ashi R, Salloum R, Saliba NA, Talhouk RS, FR Homaidan FR. Anti inflammatory properties of salograviolide a purified from lebanese plant Centaurea ainetensis. BMC Complement Altern Med 2009;9:36-5.

14. Kamble H, Kandhare A, Bodhankar S, Mohan V, Thakurdesai P. Effect of low molecular weight galactomannans from fenugreek seeds on animal models of diabetes mellitus. Biomed Aging Pathol 2013;3:145-51.

15. Honmore V, Kandhare A, Zanwar A, Rojatkar S, Bodhankar S, Natu A. Artemisia pallens alleviates acetaminophen induced toxicity via modulation of endogenous biomarkers. Pharm Biol 2015;53:571-81.

16. Kandhare A, Raygude K, Ghosh P, Bodhankar S. The ameliorative effect of fisetin, a bioflavonoid, on ethanolinduced and pylorus ligation-induced gastric ulcer in rats. Int J Green Pharma 2011;5:236-43.

17. Ghule AE, Kandhare AD, Jadhav SS, Zanwar AA, Bodhankar SL. Omega-3-fatty acid adds to the protective effect of flax lignan concentrate in pressure overload-induced myocardial hypertrophy in rats via modulation of oxidative stress and apoptosis. Int Immunopharmacol 2015;28:751-63.

18. Gosavi TP, Ghosh P, Kandhare AD, Kumar VS, Adil M, Rajmane $\mathrm{AR}$, et al. Therapeutic effect of $H$. pylori nosode, a homeopathic preparation in healing of chronic $H$. pylori infected ulcers in laboratory animals. Asian Pac J Trop Dis 2012;2:S603-S11.

19. Adil M, Visnagri A, Kumar VS, Kandhare AD, Ghosh P, Bodhankar S. Protective effect of naringin on sodium arsenite induced testicular toxicity via modulation of biochemical perturbations in experimental rats. Pharmacologia 2014;5:222-34.

20. Adil M, Kandhare AD, Ghosh P, Venkata S, Raygude KS, Bodhankar SL. Ameliorative effect of naringin in acetaminopheninduced hepatic and renal toxicity in laboratory rats: role of FXR and KIM-1. Ren Fail 2016;38:1007-20.

21. Goswami S, Kandhare AD, Zanwar AA, Hegde MV, Bodhankar SL, Shinde S, et al. Oral L-glutamine administration attenuated cutaneous wound healing in Wistar rats. Int Wound J 2016;13:116-24. 
22. Visnagri A, Kandhare AD, Kumar VS, Rajmane AR, Mohammad A, Ghosh P, et al. Elucidation of ameliorative effect of Co-enzyme Q10 in streptozotocin-induced diabetic neuropathic perturbation by modulation of electrophysiological, biochemical and behavioral markers. Biomed Aging Pathol 2012;2:157-72.

23. Tambewagh UU, Kandhare AD, Rojatkar SR. Anti-inflammatory and antioxidant potential of guaianolide isolated from Cyathocline purpurea: role of COX-2 inhibition. Int Immunopharmacol 2017;52:110-9.

24. Saraswathi KY, Muthal A, Kandhare A, Rojatkar S, Bodhankar S. Study of methanolic extract of Artemisia pallens wall on endurance of laboratory animals. Pharmacologia 2014;5:298-309.

25. Bhilare NV, Dhaneshwar SS, Sinha AJ, Kandhare AD, Bodhankar SL. Novel thioester prodrug of $\mathrm{N}$-acetylcysteine for odor masking and bioavailability enhancement. Curr Drug Delivery 2016;13:611-20.

26. Ghaisas M, Navghare V, Takawale A, Zope V, Deshpande A. In vitro antioxidant activity of Tectona grandis Linn. Pharmacologyonline 2008;3:296-5.
27. Patil M, Kandhare A, Bhise S. Pharmacological evaluation of ameliorative effect of aqueous extract of Cucumis sativus L. fruit formulation on wound healing in Wistar rats. Chronicles Young Sci 2011;2:207-13.

28. Chanda S, Dave R. In vitro models for antioxidant activity evaluation and some medicinal plants possessing antioxidant properties: an overview. Afr J Microbiol Res 2009;3:981-96.

29. Oktay M, Gülçin I, Küfrevioglu OI. Determination of in vitro antioxidant activity of fennel (Foeniculum vulgare) seed extracts. Food Sci Technol 2003;36:263-71.

30. Masferrer JL, Zweifel BS, Manning PT, Hauser SD, Leahy KM, Smith WG, et al. Selective inhibition of inducible cyclooxygenase 2 in vivo anti-inflammatory and nonulcerogenic. Proc Natl Acad Sci USA 1994;91:3228-32.

31. Smith JA. Neutrophils, host defense, and inflammation: a double-edged sword. J Leukoc Biol 1994;56:672-86. 